\title{
Influence of Earthworm Activity on Soil Microbes and Soilborne Diseases of Vegetables
}

\author{
Wade H. Elmer, Department of Plant Pathology and Ecology, The Connecticut Agricultural Experiment Station, \\ P.O. Box 1106, New Haven, CT 06504
}

\begin{abstract}
Elmer, W. H. 2009. Influence of earthworm activity on soil microbes and soilborne diseases of vegetables. Plant Dis. 93:175-179.

Earthworm densities have been regarded as reliable indicators of soil health, but their role in suppression of plant disease has not received much attention. Several greenhouse studies were done to determine if soils infested with soilborne pathogens and augmented with earthworms (Lumbricus terrestris) could reduce disease of susceptible cultivars of asparagus (Asparagus officinalis), eggplant (Solanum melongena), and tomato (Solanum lycopersicum). Soils planted with asparagus were infested with Fusarium oxysporum f. sp. asparagi and F. proliferatum, eggplant with Verticillium dahliae, and tomato with $F$. oxysporum f. sp. lycopersici Race 1 . In each host-disease system, earthworm activity was associated with an increase in plant growth and a decrease in disease. In general, plant weights were increased 60 to $80 \%$ and estimates of disease (area under the disease progress curve, percent vascular discoloration, and percent root lesions) were reduced 50 to $70 \%$ when soils were augmented with earthworms. Soil dilutions on selective media revealed that densities of fluorescent pseudomonads and filamentous actinomycetes were consistently higher for rhizosphere soils augmented with earthworms. In the studies with Verticillium wilt of eggplant, compared to the controls, the densities of total bacteria and Mn-transforming microbes were reduced in the presence of earthworms while population densities of bacilli and Trichoderma spp. were not affected. Disease suppression may have been mediated through microbiological activity. These studies suggest that strategies to increase earthworm densities in soil should suppress soilborne diseases.
\end{abstract}

Integrated management of root diseases for most organic vegetable growers is limited, especially in fields recently converted from conventional agriculture. Given that most root diseases of vegetables caused by species of Fusarium, Phytophthora, Pythium, Rhizoctonia, or Verticillium cannot be managed effectively with host resistance, growers are forced to relocate and begin long-term rotations that may last four or more years, depending on the crop and pathogen. Moreover, growers who choose to transition into organic practices may sustain major losses in the first few years when these fields are removed from conventional management (48). Efforts to increase soil quality remain the most attractive approach for reducing damage from root diseases, and there is agreement that the use of cover cropping and green manuring will, in time, provide suppression of soil pathogens $(41,43,48)$. However, the time required is dependent on several factors including choice of cover crop, rate of residue decomposition, soil

Corresponding author: Wade H. Elmer

E-mail: Wade.Elmer@po.state.ct.us

Accepted for publication 21 October 2008.

doi:10.1094/PDIS-93-2-0175

(C) 2009 The American Phytopathological Society type, and pathogen pressure. This lag period can vary considerably and may be costly for both small and large growers.

Several studies have demonstrated strong correlations between earthworm densities and parameters that define the physical and biological health of soil (12). Ever since Charles Darwin (6) conducted his classic studies with earthworms, we have understood their role as major processors of dead and decomposing organic matter. There is strong agreement that earthworms are an important component in the success of cover cropping and reducedtill crop production $(12,14)$. Physical assessments of soil quality including bulk density, pore size, water infiltration rate, soil water content, and water-holding capacity are improved by earthworm activity (12). Many consider earthworm numbers to be a reflection of soil quality $(2,33,49)$.

Additionally, studies have determined that earthworms serve crucial roles in other areas essential to healthy agroecosystems $(12,14)$. High earthworm populations increase nutrient availability $(9,42)$ and produce plant growth hormones $(1,4)$. Scheu (38) reviewed 67 earthworm studies and found that $79 \%$ reported increased plant biomass in the presence of earthworms. The deep burrows made by the earthworms, Lumbricus terrestris (Canadian night crawler) and L. rubellus (Red earthworm), break up hardpans in poorly drained soils, promote aggregate structure, and facilitate percolation $(16,26)$. Earthworms also detoxify soil by aiding in pesticide degradation, soil remediation, and land restoration (12).

More importantly, research conducted in Australia has shown that earthworms were associated with decreased incidence of field diseases of clover, grains, and grapes incited by Rhizoctonia spp. (40) and Gaeumannomyces spp. $(5,8)$. Edwards and Arancon (13) have shown that vermicomposts, an end-product of the breakdown of organic matter by earthworms, are diseasesuppressive. Earthworm castings are rich in nutrients and support a diverse microbial community $(31,36)$. Castings are also rich in calcium humate, a binding agent (12) that reduces desiccation of individual castings and favors the incubation and proliferation of beneficial organisms, such as Trichoderma spp. (47), Pseudomonas spp. (39), and mycorrhizal spores $(10,23)$. Clapperton et al. (5) showed that earthworms increase communities of gramnegative bacteria and concluded that any disease suppression was mediated by enhancing beneficial microbes. Although other microbial communities have been associated with disease suppression, such as filamentous actinomycetes (37) and Mn-reducing microbes $(17,18)$, the effect of earthworms on these communities has not been studied. The objectives of this study were to determine if the earthworm, L. terrestris, could suppress economically important soilborne diseases of asparagus, eggplant, or tomato, and to determine if consistent changes in microbial populations are associated with disease suppression.

\section{MATERIALS AND METHODS}

A series of three greenhouse experiments were conducted with asparagus, eggplant, and tomato during the winter, fall, and spring of 2005, 2006, and 2007. Adults of $L$. terrestris were periodically purchased as needed from a fishing supply house (N.A.S. Inc., Marblehead, OH). Earthworms were kept at $10^{\circ} \mathrm{C}$ for no more than 3 weeks before being washed in tap water and used in the following studies. In all experiments, plants were grown in 2liter plastic pots that were set into Styrofoam containers to prevent large fluctuations in temperature. The Styrofoam containers were interior packing material for $\mathrm{J}$. T. Baker 4-liter solvents (Mallinckrodt 
Baker, Inc., Phillipsburg, NJ) and would hold four 2-liter pots. The rims of each pot were wrapped with aluminum foil to reflect light and prevent warming and to prevent earthworms from crawling out. The bottoms of all pots were also securely wrapped and taped with nylon cloth to prevent escape. The soil mix was a 1:1 soil and peat amended with dolomitic limestone (10 g/liter). Unless otherwise stated, every 2 weeks all pots received $40 \mathrm{ml}$ of dehydrated cow manure that was passed through a 4-mm sieve (Agway, Inc., North Haven, CT). Earthworms were added at four per pot to approximate an upper field limit of 250 earthworms per $\mathrm{m}^{2}(12,14)$. Pots were set under sodium vapor lights (PL Lighting, Beamsville, ON, Canada) set on 12-h photoperiods in a greenhouse with set point temperatures of $15^{\circ} \mathrm{C}$ night and $19^{\circ} \mathrm{C}$ day. Soil temperatures were measured with soil thermometers placed $10 \mathrm{~cm}$ deep and averaged $19 \pm 3^{\circ} \mathrm{C}$. In addition, 1 to $2 \mathrm{~g}$ of ground alfalfa (Agway) was sprinkled on the soil surface once a week to serve as a food source for the earthworms. Pots were irrigated as needed with deionized water.

When experiments were terminated, plants were removed from the pots, the soil was gently shaken free from the roots, and the number of earthworms was recorded. Rhizosphere soil was sampled by shaking root systems into plastic bags and assaying the soil as described below. Plants were washed free of soil. The fresh weights of the roots and crown were recorded. Aboveground tissue was weighed separately and then air-dried at room temperature $\left(22^{\circ} \mathrm{C}\right)$ until weights were constant and weighed again.

Asparagus. Asparagus (cv. Mary Washington, Comstock Ferre Seed Co., Wethersfield, CT) seeds were disinfested by exposing them to $20 \%$ household bleach $\left(1.05 \% \mathrm{NaHClO}_{2}\right)$ for $30 \mathrm{~min}$, and then rinsing them in tap water to remove seedborne Fusarium spp. Seeds were germinated in soilless potting mix (ProMix BX, Premier Brand, New Rochelle, NY). Seedlings were fertilized every 2 weeks with 20-10-20 (N-P-K) Peter's soluble fertilizer (1.0 g/liter) (Scotts Inc., Lincoln, NE). Soil (Cheshire fine sandy loam) that was naturally infested with $F$. oxysporum f. sp. asparagi and $F$. proliferatum was removed from around the rotting crowns of asparagus plants in a field in Hamden, CT. Soil was air-dried on greenhouse benches for 1 month $\left(22\right.$ to $\left.28^{\circ} \mathrm{C}\right)$, passed through a 0.5 $\mathrm{cm}$ sieve to remove rocks and large root pieces before being mixed 1:1 with peat. Inoculum density was not enumerated due to the problem of differentiating pathogens from nonpathogens. One 14-week-old asparagus transplant was placed into each pot. There were two treatments: an earthworm treatment (four earthworms per pot) and a nonearthworm control. There were a total of 12 replicate pots per treatment.
Treatments were placed among three blocks. The study was terminated after 12 weeks. Roots were assayed for root length using the line-intersect method (45), for disease severity, and for the number of colonies of Fusarium per cm root $(17,18)$. Briefly, roots were surface-disinfested for $4 \mathrm{~min}$ in $4 \%$ household bleach $(0.21 \%$ $\mathrm{NaHClO}_{2}$ ), rinsed in deionized water, and blotted dry on paper towels. Feeder roots ( 1 to $4 \mathrm{~cm}$ long) were placed on a medium selective for Fusarium spp. $(17,18,28)$. The petri dish was placed over a 1-cm grid, and the total root length was estimated (45). The fraction of intersects with reddish lesions on the roots was also counted and used to estimate disease severity [\% root lesions $=$ (no. of intersects with root lesions/total intersects) $* 100]$. Plates were incubated at room temperature $\left(22^{\circ} \mathrm{C}\right)$ for 5 days, and the numbers of Fusarium colonies that grew from the roots were counted and used to estimate root infection (Fusarium colonies per $\mathrm{cm}$ feeder root). Between 1.5 to $2.0 \mathrm{~m}$ of feeder roots were sampled per plant. The experiment was repeated the following year.

Eggplant. Eggplant (cv. Black Beauty, Comstock Ferre Seed Co.) seeds were germinated in soilless potting mix and fertilized twice with $100 \mathrm{ml}$ of Peter's soluble 20-10-20 (N-P-K) fertilizer. Fourweek-old seedlings were transplanted into 2-liter pots filled with soil naturally infested with Verticillium dahliae. Soil (Cheshire fine sandy loam) was obtained from around the roots of severely diseased eggplants in a field in Hamden, CT, that had a history of Verticillium wilt. Soil was air-dried on greenhouse benches for 1 month, passed through a $0.5-\mathrm{cm}$ sieve to remove rocks and large root pieces, and mixed with sieved peat and limestone as described above. Soil was assayed using the method of Huisman and Ashworth (25) and found to contain $13 \pm 5$ microsclerotia per g soil. Eggplant seeds were germinated in potting mix, and one 4-week-old eggplant seedling was placed into each pot. There were four treatments: infested soil with manure (manure alone); infested soil with manure and earthworms (manure and earthworms); infested soil, no manure, but fertilized with 20-10-20 (N-P-K) Peter's soluble fertilizer (1.0 g/liter) (fertilized); and autoclaved soil, no manure, but fertilized with 20-10-20 (N-P-K) (autoclaved fertilized). Soil was autoclaved at $121^{\circ} \mathrm{C}$ for $1 \mathrm{~h}$ on consecutive days. There were eight replicate pots per treatment placed in two blocks. Plants were rated for disease development every month for 4 months on a scale of 1 to 5 where $1=$ no disease, $2=$ slightly stunted plants, $3=$ stunted and or partially wilted plants, $4=$ completely wilted plants, and $5=$ dead. The area under the disease progress curve (AUDPC) was calculated using the equation: AUDPC = $\Sigma\left(Y_{i}+Y_{i+1}\right) / 2 *\left(t_{i+1}-t_{i}\right)$, where $Y_{i}=$ disease rating at time $t_{i}$. The pathogen was reisolated from wilted stem tissue. The experiment was terminated after 4 months.

Tomatoes. Inoculum was prepared from tomato stems collected from research plots the previous year. Stems were dried, ground, passed through a 4-mm sieve, moistened with $0.025 \mathrm{M}$ asparagine (1 $\mathrm{ml} / \mathrm{g}$ residue), autoclaved for $50 \mathrm{~min}$ at $121^{\circ} \mathrm{C}$, and colonized for 2 weeks by $F$. oxysporum f. sp. lycopersici Race 1 (FRC 0 -111) then air-dried at room temperature for 1 week. The soil (topsoil, Agway) was air-dried on greenhouse benches, mixed with peat, and then amended with infested tomato stem inoculum and mixed into the soil by rotary incorporation in a cement mixer at $2 \mathrm{~g}$ inoculum per liter of soil. Earthworms were placed into soil for 4 weeks prior to transplanting one 4-weekold tomato seedling (cv. Bonny Best, Comstock Ferre Seed Co.) into each pot. There were two treatments: an earthworm treatment (four earthworms per pot) and a control (12 replicate pots per treatment placed in two blocks). The experiment was repeated the next year with six replicate pots placed in two blocks due to a shortage of healthy earthworms.

Soil assays. Rhizosphere soils were kept at $4{ }^{\circ} \mathrm{C}$ until assayed within $24 \mathrm{~h}$. Samples were bulked according to their block, and two 1-g samples were removed and serially diluted in saline ( $9 \mathrm{~g} \mathrm{NaCl} / \mathrm{liter})$. A 10fold dilution series was prepared from the rhizosphere soil, and 0.1-ml aliquots were spread onto plates of selective agar and incubated at $25^{\circ} \mathrm{C}$ in the dark. Total aerobic heterotrophic bacteria were enumerated on $10 \%$ tryptic soy agar (TSA) (4 g of TSA [Difco Laboratories, Detroit, MI), $13.5 \mathrm{~g}$ of agar, and $100 \mathrm{mg}$ of cycloheximide per liter). Endospore-forming bacilli were enumerated on $10 \%$ TSA after the suspension had been heated at $80^{\circ} \mathrm{C}$ for 10 min. Total bacteria and bacilli were enumerated after 3 days of incubation at $20^{\circ} \mathrm{C}$. Trichoderma spp. were enumerated after 5 days on Trichoderma-selective medium (7) (1.0 g Ca(NO$)_{2} 0.26 \mathrm{~g} \mathrm{KNO}_{3}$, $0.26 \mathrm{~g} \mathrm{MgSO}_{4} \cdot 7 \mathrm{H}_{2} \mathrm{O}, 0.12 \mathrm{~g} \mathrm{KH}_{2} \mathrm{PO}_{4}, 1.0$ $\mathrm{g} \mathrm{CaCl}_{2} \cdot 2 \mathrm{H}_{2} \mathrm{O}, 0.05 \mathrm{~g}$ citric acid, $1.0 \mathrm{~g}$ sucrose, $25.0 \mathrm{~g}$ agar, $1.1 \mathrm{ml}$ Igepal CA 630 [Sigma Aldrich Inc., St Louis, MO], $50 \mathrm{mg}$ chlortetracycline, $40 \mathrm{mg}$ captan $50 \mathrm{WP}$ [Bayer Crop Science, Research Triangle, $\mathrm{NC}$ ], and $5.0 \mathrm{mg}$ vinclozolin [Ronilan 50 WP, BASF Inc., Florham Park, NJ]). Fluorescent pseudomonads were enumerated on King's B agar (20 $\mathrm{g}$ of proteose peptone [Difco], $1.5 \mathrm{~g} \quad \mathrm{~K}_{2} \mathrm{HPO}_{4}, \quad 1.5 \mathrm{~g}$ of $\mathrm{MgSO}_{4} \cdot 7 \mathrm{H}_{2} \mathrm{O}, 15 \mathrm{ml}$ glycerol, and $20 \mathrm{~g}$ agar) at $20^{\circ} \mathrm{C}$ in the dark, and viewed after 2 days under UV light. Filamentous actinomycetes were enumerated after $100 \mu \mathrm{l}$ of each soil dilution had been manually spread on a sterile filter with $0.2-\mu$ m pores (BAS 83, Schleicher \& Schnell, Germany), which was placed on chitin-oatmeal agar (18 g oatmeal agar [Difco], $0.7 \mathrm{~g} \mathrm{~K}_{2} \mathrm{HPO}_{4}$, $0.3 \mathrm{~g} \mathrm{KH}_{2} \mathrm{PO}_{4}, 2 \mathrm{~g}$ colloid chitin, $12 \mathrm{~g}$ 
agar, and $100 \mathrm{mg}$ cycloheximide per liter) (37). Filters were cut into circles $(7.5 \mathrm{~cm})$, autoclaved for $20 \mathrm{~min}$, and placed onto the solidified agar. After 5 days of incubation at $25^{\circ} \mathrm{C}$ in the dark, the filters were removed, and after another 5 days incubation under the same conditions, the colonies were counted. Mn-oxidizing and Mn-reducing microbes were enumerated on Mndioxide agar (10\% TSA, $5.0 \mathrm{~g}$ Mn-dioxide, $20.0 \mathrm{~g}$ sucrose, and $15.0 \mathrm{~g}$ agar per liter) after 7 days at $20^{\circ} \mathrm{C}$ in the dark. Mn-oxidizers produced a blackened deposit, whereas Mn-reducers produced a clear zone around the colony. For all dilutions on all media, there were two plates per dilution and microbial densities were expressed as CFU per gram of soil (dry weight equivalent). Soil moisture was determined independently by air drying $1 \mathrm{~g}$ of wet soil for 2 days at room temperature, then reweighing it. Rhizosphere soil $\mathrm{pH}$ was determined by measuring 1:1 soil/water suspensions with an Accumet AR20 pH meter (Fisher Scientific, Pittsburgh, PA).

Statistical analyses. All greenhouse experiments were analyzed as randomized complete block designs using Systat V.10 (SPSS, Inc., Chicago, IL). Data based on percentages were arcsine-transformed and soil microbial data were log-transformed before being subjected to analysis of variance. Experimental repetitions were analyzed for interactions between treatment and experiment, and when no interactions were detected, the experiments were combined. Means were separated using $t$ test or Tukey tests.

\section{RESULTS}

When repetitions of the greenhouse study, regardless of vegetable, were analyzed, there were no significant interactions between treatment and repetition for any of the measured variables. Therefore, experiments from the year evaluated were combined.

Asparagus. Augmentation of the asparagus soils with earthworms led to significant increases $(P<0.001)$ in total $(78 \%)$ and root $(66 \%)$ weights when compared to controls (Table 1). Similarly, storage and feeder root lengths from earthworm-augmented pots were 42 and $18 \%$ longer than controls, respectively $(P<$ $0.05)$. Disease severity was reduced by half when earthworms were added $(P<$ 0.01 ), but no difference was detected in root colonization by $F$. oxysporum between earthworm-treated soil and the controls. This may be due to the inability to distinguish pathogenic colonies of Fusarium sp. from nonpathogenic ones.

Eggplant. Earthworms did not increase eggplant weights when compared to controls (Table 2). Plants fertilized with 20-1020 fertilizer, however, had markedly increased plant weights, regardless of whether the soil was infested or autoclaved. On the other hand, when disease ratings were integrated, plants that received earthworms had no disease symptoms, as did eggplants grown in autoclaved soil. In the absence of earthworms, plants grown in Verticillium-infested soil had significant disease, regardless of whether they were treated with manure or 20-10-20 fertilizer.

Tomato. Earthworms added to Fusarium-infested tomato soil produced plants that were $78 \%$ larger $(P<0.001)$, had twice as many fruit $(P<0.01)$, and weighed almost three times as much $(P<$ 0.001 ) as the control plants (Table 3 ). The percentage of vascular discoloration in the stem was reduced along with a $68 \%$ reduction in AUDPC.

In all three studies with asparagus, eggplant, and tomato, there were consistent and significant increases in numbers of fluorescent pseudomonads and filamentous actinomycetes in the rhizosphere soil (Table 4). The eggplant studies revealed that earthworm activity was associated with a near 10-fold increase in total bacteria and a 10-fold decrease in the Mn-transforming microbes. Populations of bacilli and Trichoderma spp. were not influenced by earthworm activity in any of the three studies. Soil $\mathrm{pH}$ in all the soils augmented with earthworms increased slightly ( 0.2 to 0.3 units) (data not shown).

\section{DISCUSSION}

Even though hundreds of articles have been published documenting improved physical and biological characteristics of soil and enhanced fertility levels with earthworms $(12,14,29,38)$, only a small number of studies report their influence on disease suppression $(5,8,13,34,35,40,50)$. The current study found that earthworm activity could increase plant growth and suppress disease within three separate vegetable systems. In each system, the microbial communities consistently affected were fluorescent pseudomonads and filamentous actinomycetes. Since these microbial groups are implicated in disease suppression $(22,30)$, it is reasonable to assume they may be contributing to the disease suppression in the current study. These microbes are common to most soils, so it was hypothesized that earthworms alone might be able to transform diseaseconducive soils into disease-suppressive soils. This further suggests that as earthworms tunnel, they fill their burrows with microbially rich castings. Rapidly growing roots could quickly occupy these burrows and become exposed to high densities of beneficial organisms that may improve root health by mechanisms such as competition, antagonism, and/or induced resistance $(22,30,44)$. Nakamura (34) suggested that the practice of augmenting soil with earthworms may speed the recovery of problem soils back to productivity by restoring beneficial microflora. Others have suggested that earthworm feeding reduces the survival of plant pathogens as they pass through earthworm guts $(32,50)$.

Although fertility was not examined in these studies, it is well recognized that earthworm activity increases the availability of nutrients $(9,31,38)$, specifically nitrates (42). Fusarium diseases are decreased under nitrate-N regimes by mechanisms that include root-mediated changes in $\mathrm{pH}$, in microbial activity, and in the availability of micronutrients such as $\mathrm{Cu}, \mathrm{Fe}, \mathrm{Mn}$, and $\mathrm{Zn}$ (24). The role of these elements in disease suppression has been recently reviewed $(11,20,21,46)$. Interest-

Table 2. Influence of earthworms (Lumbricus terrestris) on eggplant growth and disease severity of Verticillium wilt in greenhouse studies

\begin{tabular}{lccc}
\hline Treatment & Dry plant weight $(\mathbf{g})$ & AUDPC $^{\mathbf{y}}$ & Earthworms recovered \\
\hline Manure alone & $3.8 \mathrm{a}^{\mathrm{z}}$ & $117 \mathrm{a}$ & 0 \\
Manure - earthworms & $4.0 \mathrm{a}$ & $91 \mathrm{~b}$ & 5.57 \\
Fertilized & $10.3 \mathrm{~b}$ & $163 \mathrm{a}$ & 0 \\
Autoclaved - fertilized & $8.2 \mathrm{~b}$ & $91 \mathrm{~b}$ & 0 \\
\hline
\end{tabular}

${ }^{\mathrm{y}}$ Area under the disease progress curve based on weekly estimates of disease severity; AUDPC = $\Sigma\left(Y_{i}+Y_{i+1}\right) / 2 *\left(t_{i+1}-t_{i}\right)$, where $Y_{i}=$ disease rating at time $t_{i}$.

${ }^{z}$ Values followed by differing letters are significantly different according to Tukey's test at $P=0.05$.

Table 1. Influence of earthworms (Lumbricus terrestris) on asparagus growth, disease severity, and root colonization by Fusarium oxysporum f. sp. asparagi and $F$. proliferatum in greenhouse studies

\begin{tabular}{|c|c|c|c|c|c|c|c|}
\hline \multirow[b]{2}{*}{ Treatment } & \multicolumn{2}{|c|}{ Plant weights (g) } & \multicolumn{2}{|c|}{ Root length $(\mathrm{m})^{\mathrm{y}}$} & \multirow{2}{*}{$\begin{array}{l}\text { Percent root } \\
\text { lesions }\end{array}$} & \multirow{2}{*}{$\begin{array}{c}\text { Fusarium } \\
\text { colonies/cm root }\end{array}$} & \multirow{2}{*}{$\begin{array}{c}\text { Earthworms } \\
\text { recovered }\end{array}$} \\
\hline & Total & Roots & Storage & Feeder & & & \\
\hline Control & 27.3 & 18.5 & 1.83 & 3.01 & 14.0 & 0.34 & 0 \\
\hline Earthworms & $43.2 * * * \mathrm{z}$ & $30.7 * * *$ & $2.59 *$ & $3.55^{*}$ & $7.0 * *$ & 0.38 & $4.15^{* * * *}$ \\
\hline
\end{tabular}

${ }^{\mathrm{y}}$ Root length was estimated using the line intersect method.

$\mathrm{z} * * *$, or *** indicates statistically significant differences between sample means based on $t$ test at $P<0.05,<0.01$, or $<0.001$, respectively. 
Table 3. Influence of earthworms (Lumbricus terrestris) on tomato growth and severity of Fusarium wilt in greenhouse studies

\begin{tabular}{|c|c|c|c|c|c|c|}
\hline Treatment & Plant weight (g) & No. fruit & Fruit weight (g) & Vas. dis. ${ }^{x}$ & AUDPC $^{\mathbf{y}}$ & Earthworms recovered \\
\hline Control & 20.6 & 0.6 & 9.2 & 51.2 & 60.1 & 0 \\
\hline Earthworms & $36.7 * * * \mathrm{z}$ & $1.3^{* *}$ & $25.4 * * *$ & $30.8^{* *}$ & $19.5^{* *}$ & $3.80 * * *$ \\
\hline
\end{tabular}

$\mathrm{x}$ Percent vascular discoloration (statistics done on arcsine transformed values).

y Area under the disease progress curve based on weekly estimates of disease severity.

$\mathrm{z} *, * *$, or $* * *$ indicates statistically significant differences between sample means based on $t$ test at $P<0.05,<0.01$, or $<0.001$, respectively.

Table 4. Influence of earthworms (Lumbricus terrestris) on microbial communities in pathogen-infested soils from the rhizosphere of asparagus, eggplants, and tomatoes grown in the greenhouse

\begin{tabular}{|c|c|c|c|c|c|c|c|}
\hline \multirow[b]{2}{*}{ Plant treatment } & \multicolumn{7}{|c|}{ Log CFU/g soil (dry weight equivalent) } \\
\hline & $\begin{array}{c}\text { Fluorescent } \\
\text { pseudomonads }\end{array}$ & $\begin{array}{c}\text { Filamentous } \\
\text { actinomycete }\end{array}$ & Bacilli & Total bacteria & Mn-oxidizers & Mn-reducers & Trichoderma \\
\hline \multicolumn{8}{|l|}{ Asparagus } \\
\hline Control & 5.61 & 5.83 & 6.67 & 7.25 & 5.73 & 4.96 & $-\mathrm{x}$ \\
\hline Earthworms & $6.30 * * y$ & $6.12 *$ & 6.65 & 7.41 & 5.32 & 4.83 & - \\
\hline \multicolumn{8}{|l|}{ Eggplant } \\
\hline Control & $4.56 \mathrm{a}^{\mathrm{z}}$ & $6.28 \mathrm{bc}$ & 6.33 & $7.33 \mathrm{a}$ & $5.61 \mathrm{a}$ & $5.31 \mathrm{a}$ & 4.23 \\
\hline Earthworms & $6.75 \mathrm{~b}$ & $6.50 \mathrm{c}$ & 6.31 & $8.15 \mathrm{~b}$ & $4.79 \mathrm{~b}$ & $4.99 \mathrm{~b}$ & 3.98 \\
\hline Control - fertilizer & $3.92 \mathrm{a}$ & $6.19 \mathrm{~b}$ & 6.19 & $7.29 \mathrm{a}$ & $5.57 \mathrm{a}$ & $5.54 \mathrm{a}$ & 4.12 \\
\hline Autoclaved - fertilizer & $4.81 \mathrm{a}$ & $5.44 \mathrm{a}$ & 6.26 & $7.01 \mathrm{a}$ & $4.51 \mathrm{~b}$ & $4.51 \mathrm{~b}$ & 4.23 \\
\hline \multicolumn{8}{|l|}{ Tomatoes } \\
\hline Control & 5.91 & 5.90 & 5.89 & 7.91 & - & - & 4.67 \\
\hline Earthworms & $6.54 * *$ & $6.12 *$ & 5.71 & 8.03 & - & - & 4.78 \\
\hline
\end{tabular}

$\mathrm{x}$ Not recorded.

y *,**, or *** indicates statistically significant differences between sample means based on $t$ test at $P<0.05,<0.01$, or $<0.001$, respectively.

z Values followed by the same letter are not significantly different according to Tukey's test at $P=0.05$.

ingly, in other studies Verticillium wilt of eggplant was suppressed by acid conditions ( $\mathrm{pH} 4.8$ to 5.2) (19), but less disease was observed in soil that had slight increases in $\mathrm{pH}$ ( 0.2 units) when compared to controls. It was not clear from this study what mechanism(s) was operating to achieve the disease suppression.

In past studies with asparagus, an association between Mn-transforming microbes and disease suppression was observed $(17,18)$. The mechanism hypothesized in those observations predicted that Mn-oxidizing microbes would decrease Mn availability and enhance disease, while Mnreducing microbes would increase $\mathrm{Mn}$ availability and suppress disease (46). Although these groups were not affected in this asparagus research, both groups were reduced in eggplant soils augmented with earthworms. Additional research with eggplants is underway to understand possible mechanisms.

Although L. terrestris was introduced to North America centuries ago by Europeans $(12,14)$, its potential in disease management has just been realized in the past two decades. L. terrestris is well adapted for use in agriculture in the northern United States since it is a long-living, cold-tolerant species that can make deep burrows beneath the frost line $(16,26)$. Most growers have recognized that earthworms are characteristic of healthy soils, but the practice of augmenting their fields with earthworms is rarely, if ever, conducted. Edwards and Lofty (15) found that introducing $L$. terrestris resulted in increased barley growth within a season and that the effects were still observed after the second season of barley. This practice has also been found useful in soil remediation studies (3), but the benefits to growers for use as a disease management strategy may not be economically feasible at present.

Once fields have been removed from conventional cultivation, earthworm densities have been reported to be relatively low (27). One obstacle in restoring earthworms in fields with low densities is the lag time required for earthworm populations to increase, which is a function of the initial level, availability of surface residues, climate, and chemical inputs $(12,14)$. Under good conditions, L. terrestris can triple its numbers in a season, but colony expansion is less than $4 \mathrm{~m} /$ year provided sufficient organic residues are present and long-distance feeding forays are unnecessary (29). However, recent advances in encapsulating earthworm cocoons (Advanced Prairie Inc., Elliott, IL, U.S. Patent 5127186) for large-scale mechanized delivery into furrows of agronomic crops may simplify the implementation of this practice and make it available and affordable for large- and small-scale growers. It is not clear at present if augmenting fields with earthworms would have more economic value than improving soil management practices and allowing resident earthworm populations to naturally increase over time, but the current study suggests earthworm management should be considered as an important component in soil health and suppression of root disease.

\section{ACKNOWLEDGMENTS}

I thank Joan Bravo and Peter Thiel for technical support.
LITERATURE CITED

1. Atiyeh, R. M., Lee, S., Edwards, C. A., Arancon, N. Q., and Metzger, J. D. 2002. The influence of humic acids derived from earthwormprocessed organic wastes on plant growth. Bioresource Technol. 84:7-14.

2. Buckerfield, J. C., Lee, K. E., Davoren, C. W., and Hannay, J. N. 1997. Earthworms as indicators of sustainable production in dryland cropping in Southern Australia. Soil Biol Biochem. 29:547-554

3. Butt, K. R., Frederikson, J., and Morris, R. M 1992. The intensive production of Lumbricus terrestris for soil remediation (Oloigachaeta Lumbricida). Pedobiologia 35:257-264.

4. Canellas, L. P., Olivares, F. L., OkorokovaFaçanha, A. L., and Façanha, A. R. 2002. Humic acids isolated from earthworm compost enhance root elongation. Lateral root emergence and plasma membrane $\mathrm{H}^{+}$-ATPase activity in maize roots. Plant Physiol. 130:1951-1957.

5. Clapperton, M. J., Lee, N. O., Binet, F., and Conner, R. L. 2001. Earthworms indirectly reduce the effect of take-all (Gaeumannomyces graminis var. tritici) on soft white spring wheat (Triticium aestivum cv. Fielder). Soil Biol. Biochem. 33:1531-1538.

6. Darwin, C. 1881. The formation of vegetable mould through the action of worms and observation on their habits. Murray Publishing Co., London.

7. Davet, P. 1979. Technique pour l'analyse des populations de Trichoderma et de Gliocladium virens dans le sol. Ann. Phytopathol. 11:259533.

8. Davoren, C. W., Ryder, M. H., and Doube, B. M. 1994. Ability of lumbricid earthworms Aporrectodea rosea and A. trapezoids to reduce the severity of take-all under greenhouse and field conditions. Soil Biol. Biochem. 26:1291-1297.

9. Devliegher, W., and Verstraete, W. 1997. The effect of Lumbricus terrestris on soil in relation to plant growth: Effects of nutrientenrichment processes (NEP) and gutassociated processes (GAP) Source. Soil Biol. Biochem. 29:341-346. 
10. Doube, B. M., Ryder, M. H., Davoren, C. W., and Meyer, T. 1995. Earthworms: A down under delivery system service for biocontrol agents of root disease. Acta Zool. Fennica 196:219-223

11. Duffy, B. 2007. Zinc and plant disease. Pages 155-176 in: Mineral Nutrition and Plant Disease. L. E. Datnoff, W. H. Elmer, and D. M. Huber, eds. American Phytopathological Society, St. Paul, MN.

12. Edwards, C. A., ed. 1998. Earthworm Ecology. American Soil and Water Conservation Association. CRC Press, Boca Raton, FL.

13. Edwards, C. A., and Arancon, N. Q. 2004. Vermicomposts suppress plant pest and disease attacks. BioCycle 45:51-53.

14. Edwards, C. A., and Bohlen, P. J. 1996. The Biology and Ecology of Earthworms, 3rd ed. Chapman \& Hall, London.

15. Edwards, C. A., and Lofty, J. R. 1980. Effect of earthworm inoculation upon the root growth of direct drilled cereals. J. Appl. Ecol. 17:533-543.

16. Ehlers, W. 1975. Observations on earthworm channels and infiltration on tilled and untilled loess soil. Soil Sci. 119:242-249.

17. Elmer, W. H. 1995. Association between Mnreducing root bacteria and $\mathrm{NaCl}$ applications in suppression of Fusarium crown and root rot of asparagus. Phytopathology 85:1461-1467.

18. Elmer, W. H. 2003. Local and systemic effects of $\mathrm{NaCl}$ on root composition, rhizobacteria, and Fusarium crown and root rot of asparagus. Phytopathology 93:186-192.

19. Elmer, W. H., and Ferrandino, F. J. 1994. Comparison of ammonium sulfate and calcium nitrate fertilization effects on Verticillium wilt of eggplant. Plant Dis. 78:811-816.

20. Evans, I., Solberg, E., and Huber, D. M. 2007. Copper and plant disease. Pages 177-188 in: Mineral Nutrition and Plant Disease. L. E. Datnoff, W. H. Elmer, and D. M. Huber, eds. American Phytopathological Society, St. Paul, $\mathrm{MN}$

21. Expert, D. 2007. Iron and plant disease. Pages 119-138 in: Mineral Nutrition and Plant Disease. L. E. Datnoff, W. H. Elmer, and D. M. Huber, eds. American Phytopathological Society, St. Paul, MN.

22. Fravel, D. R. 1988. Role of antibiosis in the biocontrol of plant diseases. Annu. Rev. Phytopathol. 26:75-91.

23. Gange, A. C. 1993. Translocation of mycorrhizal fungi by earthworms during early succession. Soil Biol. Biochem. 25:1021-1026.

24. Huber, D. M., and Thompson, I. A. 2007. Nitrogen and plant disease. Pages 31-44 in: Mineral Nutrition and Plant Disease. L. E.
Datnoff, W. H. Elmer, and D. M. Huber, eds. American Phytopathological Society, St. Paul, $\mathrm{MN}$.

25. Huisman, O. C., and Ashworth, L. J., Jr. 1974. Verticillium albo-atrum: Quantitative isolation of microsclerotia from field soils. Phytopathology 64:1159-1163.

26. Joschko, M., Diestel, H., and Larink, O. 1982. Assessment of earthworm burrowing efficiency in compacted soil with a combination of morphological and soil physical measurements. Biol. Fert. Soils 8:191-196.

27. Kladivko, E. J., Akhouri, N. M., and Weesies, G. 1997. Earthworm populations and species distributions under no-till and conventional tillage in Indiana and Illinois. Soil Biol. Biochem. 29:613-615.

28. Komada, H. 1975. Development of selective medium for quantitative isolation of Fusarium oxysporum from natural soil. Rev. Plant Prot. Res. 8:114-124.

29. Lee, K. E. 1985. Earthworms, their ecology and relationships with soils and land use. Academic Press, New York.

30. Lemanceau, P., and Alabouvette, C. 1993. Suppression of Fusarium wilts by fluorescent pseudomonads: Mechanisms and applications. Biocontrol Sci. Technol. 3:219-234.

31. Lunt, H. A., and Jacobson, H. G. M. 1944. The chemical composition of earthworm casts. Soil Sci. 58:367-375.

32. Moody, S. A., Piearce, T. G., and Dighton, J., 1996. Fate of some fungal spores associated with wheat straw decomposition on passage through the guts of Lumbricus terrestris and Aporrectodea longa. Soil Biol. Biochem. 28:533-537.

33. Muys, B., and Granval, P. 1997. Earthworms as bio-indicators of forest site quality. Soil Biol. Biochem. 29:323-328.

34. Nakamura, Y. 1996. Interactions between earthworms and microorganisms in biological control of plant root pathogens. Farming Jpn. 30:37-43

35. Nakamura, Y., Itakura, J., and Matsuzaki, I. 1995. Influence of the earthworm Pheretima hilgendorfi (Megascolecidae) on Plasmodiophora brassicae clubroot galls of cabbage seedlings in pot. Edaphologia 54:39-41.

36. Parle, J. N. 1963. A microbiological study of earthworm casts. J. Gen. Microbiol. 31:13-22.

37. Postma, J., Geraats, B. P. J., Pastoor, R., and van Elsas, J. D. 2005. Characterization of the microbial community involved in the suppression of Pythium aphanidermatum in cucumber grown on rockwool. Phytopathology 95:808818.
38. Scheu, S. 2003. Effect of earthworms on plant growth: Patterns and perspectives. Pedobiologia 47:846-856.

39. Schmidt, O., Doubre, B. M., Ryder, M. H., and Killman, K. 1997. Population dynamics of Pseudomonas corrugata 2140R LUX8 in earthworm food and in earthworm cast. Soil Biol. Biochem. 29:523-528.

40. Stephens, P. M., and Davoren, C. W. 1997. Influence of earthworm Aporrectodea trape zoides $A$. rosea on the disease severity of Rhizoctonia solani on subterranean clover and ryegrass. Soil Biol. Biochem. 29:511-516.

41. Stone, A. G., Scheuerell, S. J., and Darby, J. M. 2004. Suppression of soilborne diseases in field agricultural systems: Organic matter management, cover cropping, and other cultural practices. Pages 131-177 in: Soil Organic Matter in Sustainable Agriculture. F. Magdoff and R. Weil, eds. CRC Press, Boca Raton, FL.

42. Subler, S., Baranski, C. M., and Edwards, C. A. 1997. Earthworm additions increased shortterm nitrogen availability and leaching in two grain-crop agroecosystems. Soil Biol. Biochem. 29:413-421.

43. Sumner, D. R., Doupnik, B., Jr., and Boosalis, M. G. 1981. Effects of reduced tillage and multiple cropping on plant diseases. Annu. Rev. Phytopathol. 19:167-187.

44. Szczech, M., Kowalska, B., and Smolinska, U. 2002. Induction of systemic resistance in radish by pseudomonads developing in vermicompost-amended substrate. Phytopathol. Polonica 24:57-66.

45. Tennant, D. 1975. A test of modified lineintersect method for estimating root length. J. Ecol. 63:995-1001.

46. Thompson, I. A., and Huber, D. M. 2007. Manganese and plant disease. Pages 139-154 in: Mineral Nutrition and Plant Disease. L. E. Datnoff, W. H. Elmer, and D. M Huber, eds. American Phytopathological Society, St. Paul, MN

47. Tiunov, A. V., and Scheu, S. 2000. Microfungal communities in soil litter and casts of Lumbricus terrestris (Lumbricidae): A laboratory experiment. Appl. Soil Ecol. 14:17-26.

48. van Bruggen, A. C., and Termorshuizen, A. J. 2003. Integrated approaches to root disease management in organic farming systems. Australas. Plant Pathol. 32:141-156.

49. Wolfe, D. W. 2001. Tales from the underground: A natural history of subterranean life. Perseus Publishing, Cambridge, MA.

50. Yeates, G. W. 1981. Soil nematode populations depressed in the presence of earthworms. Pedobiologia 22:191-202. 